KOVID-19 INFEKCIJA IZ ASPEKTA GASTROENTEROLOGA

PREGLEDNI RAD

REVIEW ARTICLE

\title{
THE COVID-19 INFECTION FROM THE PERSPECTIVE OF THE GASTROENTEROLOGIST
}

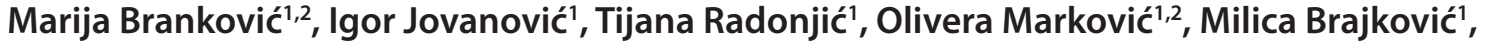 \\ Višeslav Popadić', Slobodan Klašnja ${ }^{1}$, Marija Zdravković',
}

\author{
1 Kliničko-bolnički centar „Bežanijska Kosa“, Beograd, Srbija \\ 2 Medicinski fakultet, Univerzitet u Beogradu, Beograd, Srbija
}

\author{
1 University Hospital Medical Center Bežanijska Kosa, Belgrade, \\ Serbia \\ 2 Faculty of Medicine, University of Belgrade, Belgrade, Serbia
}

\begin{abstract}
SAŽETAK
Gastrointestinalni trakt i jetra nisu pošteđeni kada je u pitanju bolest izazvana koronavirusom 2019 (KOVID-19), jer ona ne utiče samo na respiratorni trakt, već je takođe sistemska bolest koja prouzrokuje oštećenje više organa. U ovom preglednom radu, ujedinili smo sve podatke klinički značajne za lekare koji leče pacijente obolele od ove infekcije, posebno za gastroenterologe. Treba imati na umu da gastrointestinalni simptomi mogu biti prvi i/ili jedini pokazatelji KOVID-19 infekcije, stoga treba posumnjati na ovu infekciju kada pacijent, koji je bio izložen riziku, prijavi simptome poput proliva, gubitka apetita, bola u trbuhu, mučnine i/ ili povraćanja. Gornja gastrointestinalna endoskopija tokom pandemije KOVID-19 infekcije predstavlja veliki problem, jer je reč o infekciji koja se tokom ove procedure vrlo lako prenosi kapljičnim putem, stoga je treba sprovoditi samo u hitnim slučajevima. Što se tiče pacijenata koji boluju od inflamatornih bolesti creva, oni su često na imunosupresivnoj terapiji, ali preporuke su da im ne treba korigovati terapiju jer nisu u grupi pacijenata sa povećanim rizikom od oboljevanja od KOVID-19 infekcije. Takođe, lezija jetre prouzrokovana ovom infekcijom je rezultat mehanizama više faktora i zasigurno predstavlja razlog za brigu, pogotovo ako su u pitanju pacijenti sa već postojećim, hroničnim bolestima jetre, te na njih treba posebno obratiti pažnju.
\end{abstract}

Ključne reči: KOVID-19, gastrointestinalni trakt, jetra, inflamatorne bolesti creva, endoskopija.

\begin{abstract}
The gastrointestinal tract and liver are not spared, when it comes to the coronavirus disease of 2019 (COVID-19), as it doesn't only affect the respiratory tract, but it is also a systemic disease that causes multiple organ damage. In this review, we have united all information that is clinically significant for physicians dealing with this infection, especially for gastroenterologists. One must bear in mind that gastrointestinal symptoms can be the first and/or only indicators of COVID-19, so this infection needs to be suspected when a patient at risk presents with diarrhea, loss of appetite, abdominal pain, nausea, and/or vomiting. Upper gastrointestinal endoscopy in the COVID-19 pandemic is a major issue, as transmission of this airborne infection happens very easily during this procedure, and it should be performed only in cases of gastrointestinal emergencies. With regard to patients suffering from inflammatory bowel disease (IBD), they are often on immunosuppressive therapy, but recommendations are that no change in therapy should be made, as these patients do not fall under the category of patients who are at increased risk of contracting COVID-19. In addition, liver lesion caused by this infection develops as the result of a multifactorial mechanism and is a definite cause for concern, especially in patients with pre-existing chronic liver conditions, who should be closely monitored.
\end{abstract}

Keywords: COVID-19, gastrointestinal tract, liver, inflammatory bowel disease, endoscopy 


\section{UVOD}

Prvi slučaj bolesti KOVID-19, prouzrokovane tipom 2 koronavirusa - izazivačem teškog akutnog respiratornog sindroma (SARS-KoV-2) (engl. severe acute respiratory syndrome coronavirus 2 - SARS-CoV-2) registrovan je u kineskom gradu Vuhanu, u decembru 2019. godine [1]. Sve je počelo kada je zabeleženo nekoliko slučajeva upale pluća nepoznate etiologije u tom gradu [2]. Sada je dobro poznato da je reč o teškom akutnom respiratornom sindromu izazvanom tipom 2 koronavirusa, novom vrstom ljudskog Betakoronavirusa [3]. Koronavirusi su porodica jednolančanih RNK virusa sa omotačem. Sekvenca genoma SARS-KoV-2 virusa ima 82,0\% sličnosti sa SARS-KoV virusom [4]. SARS-KoV-2 virus se izuzetno brzo širio kapljičnim putem, što je rezultiralo svetskom pandemijom, koja je i proglašena, 11. marta 2020. godine, od strane Svetske zdravstvene organizacije [5].

Prve manifestacije ove bolesti su najčešće simptomi respiratornog trakta, ali sada je već dobro poznato da je KOVID-19 sistemska bolest koja oštećuje više organa. Ovo se može objasniti receptorom angiotenzin konvertujućeg enzima 2 (engl. angiotensin-converting enzyme - ACE2) putem kojeg virus ulazi u ćeliju [6]. ACE2 receptori se nalaze $u$ alveolarnim ćelijama tipa 2 u plućima, u glandularnim ćelijama želuca, u epitelnim ćelijama enterocita, $u$ ileumu i kolonu, $u$ većini holangiocita, i u manje od 3,0\% hepatocita [7-9].

\section{GASTROINTESTINALNI TRAKT}

Najčešći gastrointestinalni simptomi KOVID-19 infekcije su proliv, bol u trbuhu, mučnina, povraćanje i gubitak apetita [10]. Gastrointestinalni simptomi su prisutni kod $3,0 \%$ do $39,6 \%$ pacijenata obolelih od KOVID-19 oboljenja, a od tih simptoma je najčešći proliv [6]. Kao što je već navedeno, bolest KOVID-19 obično napada respiratorni trakt i prouzrokuje povišenu telesnu temperaturu, kašalj i malaksalost [10], ali takođe izaziva gastrointestinalne tegobe koji mogu biti prvi i jedini simptomi ove infekcije [6].

I dalje nije pronađen odgovor na pitanje da li je gastrointestinalni trakt potencijalni put prenosa ove infekcije (fekalno-oralni put prenosa). Čak ni sada, nakon više od godinu dana od kako je počela pandemija, uzorak stolice se ne koristi u svakodnevnoj praksi radi postavljanja dijagnoze KOVID-19 infekcije. Kao i do sada, zlatni standard je nazofaringealni bris, iako je dokazano prisustvo RNK SARS-KoV-2 virusa i u stolici pacijenata [11]. Osim toga, u uzorku stolice se mogla izolovati RNK SARS-KoV-2 virusa i nakon negativnog nazofaringealnog brisa [12]. Stoga se može pretpostaviti da se, ovim načinom, infekcija može preneti, iako virus više nije prisutan u respiratornom traktu [13].

\section{INTRODUCTION}

The first case of the coronavirus disease of 2019 (COVID-19), caused by severe acute respiratory syndrome coronavirus 2 (SARS-CoV-2) was registered in the Chinese city of Wuhan, in December 2019 [1]. It all started when several cases of pneumonia of unknown etiology appeared in that city [2]. Now we know that severe acute respiratory syndrome coronavirus 2 is a new type of human-infecting Betacoronavirus [3]. Coronaviruses are a family of single-stranded enveloped ribonucleic acid (RNA) viruses. The genome sequence of SARS-CoV-2 is $82.0 \%$ similar to SARS-CoV [4]. SARS-CoV-2 spread quickly via respiratory droplets which resulted in a global pandemic that was, in fact, declared by the World Health Organization on March 11, 2020 [5].

Usually, the first manifestation of this disease are respiratory tract symptoms, but it is known that COVID-19 is a systemic disease with multiple organ damage. This can be explained by the receptor of angiotensin-converting enzyme 2 (ACE2) which is a way for a virus to enter a cell [6]. In alveolar cells type 2 in lungs, in the glandular cells of stomach, in epithelial cells of enterocytes in ileum and colon, in most of the cholangiocytes and in less than $3.0 \%$ of hepatocytes [7] ACE2 receptors can be found [8,9].

\section{THE GASTROINTESTINAL TRACT}

The most commonly reported gastrointestinal tract (GIT) symptoms of COVID-19 are diarrhea, abdominal pain, nausea, vomiting and loss of appetite [10]. Gastrointestinal symptoms are present in $3.0 \%$ to $39.6 \%$ of COVID-19 patients and diarrhea is the symptom most commonly reported [6]. As already stated, COVID-19 typically affects the respiratory tract and causes fever, cough and fatigue [10], but also gastrointestinal symptoms, which can be the first and only symptoms of this infection [6].

The question of whether the gastrointestinal tract can be a potential route of transmission of this infection (fecal-oral route) remains open. Even now, after more than a year has passed since the start of the pandemic, stool samples are normally not used for diagnosing COVID-19. The nasopharyngeal swab remains the golden standard, although it has been proven that SARS-CoV-2 RNA is also present in the patients' stool [11]. Furthermore, there is a report indicating that stool samples remained positive for SARS-CoV-2 RNA longer than nasopharyngeal swabs [12]. Therefore, it can be presumed that this mode of transmission may occur even after the virus is cleared from the respiratory tract [13]. 


\section{Endoskopske procedure}

Gornja i donja gastrointestinalna (GI) endoskopija predstavlja problem u pandemiji KOVID-19 oboljenja. Kako endoskopske procedure zahtevaju blizak kontakt endoskopiste i pacijenta, postoji veliki rizik od prenošenja infekcije, posebno u slučaju one koja se prenosi kapljičnim putem, kao što je KOVID-19 infekcija, a koja ima i mogući način prenošenja fekalno-oralnim putem. Zbog svega navedenog, endoskopske procedure treba raditi samo u slučajevima akutnog gastrointestinalnog krvarenja, a čak i tada, ponekad pacijente možemo lečiti konzervativno, u slučaju krvarenja iz gornjih partija gastrointestinalnog trakta, i to maksimalnim dozama inhibitora protonske pumpe.

Gornjom gastrointestinalnom endoskopijom kod KOVID-19 pacijenata, viđene su mukozne erozije i ulceracije, poput herpesnih, dok su biopsije potvrdile prisustvo SARS-KoV-2 virusa [14]. Kao što je već navedeno, gornja gastrointestinalna endoskopija je uglavnom potrebna u slučaju akutnog gastrointestinalnog krvarenja, koje može biti objašnjeno kao neželjeno dejstvo primene niskomolekularnog heparina, koji se ordinira pacijentima kao profilaksa za sprečavanje tromboembolijskih događaja prouzrokovanih KOVID-19 infekcijom i/ili diseminovane intravaskularne koagulacije, koja je često posledica sepse [15].

Kao što znamo, RNK SARS-KoV-2 virusa je prisutna u stolici pacijenta [11], stoga donje endoskopske procedure takođe nose veliki rizik od prenošenja infekcije. Proliv i krvarenje iz donjih partija gastrointestinalnog trakta se takođe često sreću kod pacijenata sa KOVID-19 infekcijom. Donje endoskopske procedure

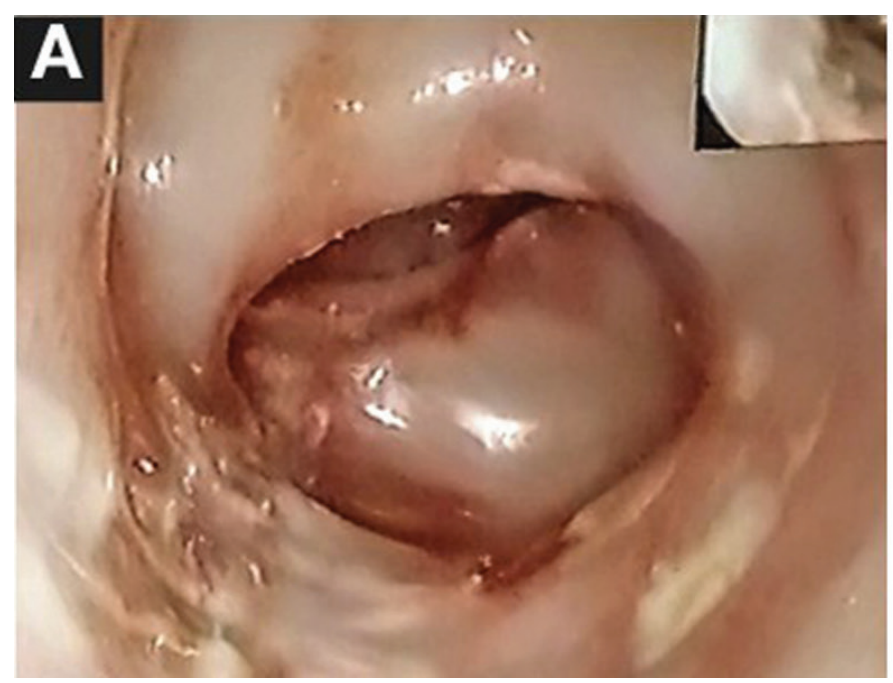

Slika 1. Nalazi donje endoskopije kod pacijenata obolelih od KOVID-19 oboljenja; Ishemijske promene na debelom crevu (A) i segmentni kolitis povezan sa divertikulozom (B)

Preuzeto sa: https://doi.org/10.1016/j.cgh.2020.05.045. (Massironi S, Viganò C, Dioscoridi L, Filippi E, Pagliarulo M, Manfredi G, et al. Endoscopic Findings in Patients Infected with 2019 Novel Coronavirus in Lombardy, Italy. Clin Gastroenterol Hepatol. 2020;18(10):2375-2377).

\section{Endoscopic procedures}

Upper and lower gastrointestinal (GI) endoscopy is an issue during the COVID-19 pandemic. As such procedures require close contact of the endoscopist and the patient, there is a high risk of infection transmission, especially in case of airborne infection, like this one, with a possible fecal-oral route of transmission. This is why endoscopic procedures should be done only in case of acute gastrointestinal bleeding, and even then, sometimes, patients can be treated conservatively for upper GI bleeding with maximal doses of proton-pump inhibitors.

Upper gastrointestinal endoscopy performed in COVID-19 patients has revealed mucosal herpetic-like erosions and ulcers, and biopsy has confirmed the presence of SARS-CoV-2 [14]. As already mentioned above, upper gastrointestinal endoscopy is usually required in case of acute gastrointestinal bleeding, which is explained as a possible adverse event of low molecular weight heparin treatment, administered as prophylaxis for preventing thromboembolic events in COVID-19 infection and/or intravascular coagulation, which is often a consequence of sepsis [15].

As already mentioned, SARS-CoV-2 RNA is present in the patients' stool [11], which is why lower endoscopy procedures also carry a high risk of infection transmission. Diarrhea and lower gastrointestinal bleeding are also frequently reported in COVID-19 patients. Lower endoscopic procedures often reveal ulcerative colonic lesions, but diverticulosis or colonic ischemia, as well (Figure 1) [15]. Ischemic colitis is thought to be the effect of hypercoagulability and endothelial dysfunction caused by SARS-CoV-2 [15].

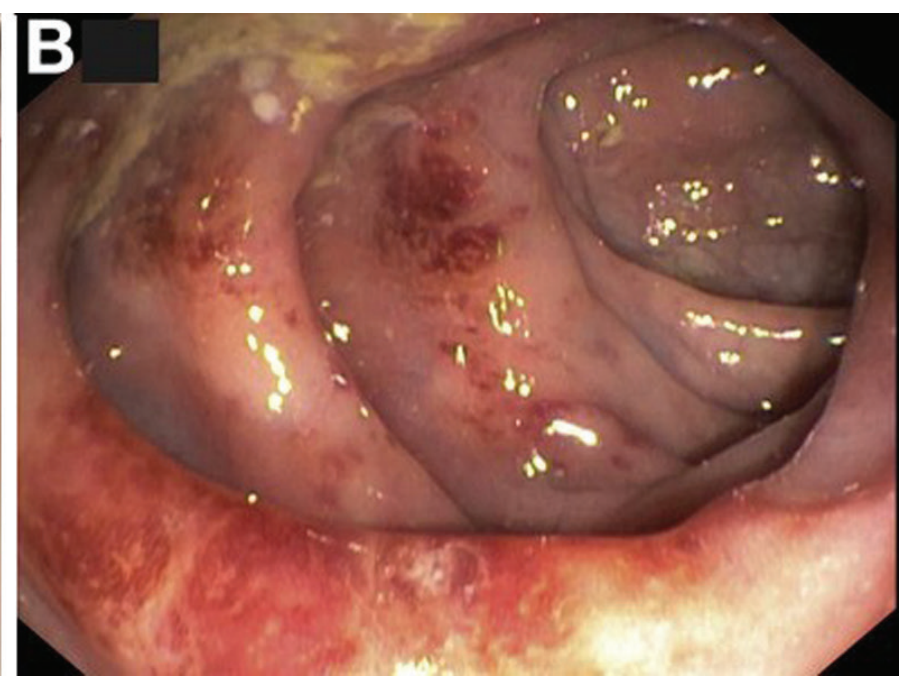

Figure 1. Lower endoscopy findings in COVID-19 patients; Colon ischemia (A) and segmental colitis associated with diverticulosis (B)

From: https://doi.org/10.1016/j.cgh.2020.05.045. (Massironi S, Viganò C, Dioscoridi L, Filippi E, Pagliarulo M, Manfredi G, et al. Endoscopic Findings in Patients Infected with 2019 Novel Coronavirus in Lombardy, Italy. Clin Gastroenterol Hepatol. 2020;18(10):2375-2377). 
često ukazuju na ulceracije u debelom crevu, ali se takođe viđa divertikuloza ili ishemija debelog creva (Slika 1) [15]. Ishemijski kolitis je verovatno posledica hiperkoagulabilnosti i endotelne disfunkcije, koje su prouzrokovane SARS-KoV-2 virusom [15].

\section{Pacijenti oboleli od inflamatornih bolesti creva}

Starosno doba, muški pol i pridružene bolesti pacijenta (arterijska hipertenzija, šećerna bolest, maligniteti, kardiovaskularne i cerebrovaskularne bolesti) utiču na veću stopu mortaliteta kod pacijenata obolelih od KOVID-19 oboljenja [16]. U gastroenterologiji, postoji veliki broj pacijenata koji su oboleli od inflamatornih bolesti creva (engl. inflammatory bowel disease - IBD), a neki imaju još pridruženih bolesti. Ti pacijenti su različite starosti, nezavisno od pola, te na prvi pogled imaju prioritet da se ne zaraze virusom SARS-KoV-2. Uz to, dosta pacijenata obolelih od inflamatornih bolesti creva je na imunosupresivnoj ili biološkoj terapiji. S obzirom na način delovanja ovih lekova, postoji veći rizik za dobijanje infekcije. Kako KOVID-19 oboljenje prouzrokuje citokinsku oluju, imunosupresivni lekovi, u ovom slučaju, mogu preduprediti pneumoniju kod KOVID-19 infekcije [17]. Sve u svemu, preporuke za pacijente sa IBD-om savetuju da treba nastaviti sa redovnom terapijom, jer nije dokazano da su ovi pacijenti izloženi većem riziku od oboljevanja od KOVID-19 infekcije, ali se ti pacijenti moraju pomno pratiti [17].

\section{Inflammatory bowel disease patients}

A higher mortality rate in COVID-19 is related to advanced age, the male gender and comorbidities of the patient (arterial hypertension, diabetes mellitus, malignancies, cardiovascular and cerebrovascular diseases) [16]. In gastroenterology, there is a large number of patients with inflammatory bowel disease (IBD) and other comorbidities, who, independent of gender, belong to different age groups. Therefore, they are obviously a priority to not get infected with SARS-CoV-2. Additionally, many IBD patients are on immunosuppressive therapy or on biological therapy. Due to their treatment mechanism, these drugs lead to increased risk of infection. Since COVID-19 causes the cytokine storm, immunosuppressive drugs may prevent COVID-19 pneumonia [17]. Overall, recommendations for IBD patients suggest that they should continue with their usual therapy, since there is no evidence of increased risk of contracting the COVID-19 infection, however, these patients should be monitored closely [17].

\section{HEPATOLOGY}

After the lungs, the second organ most commonly affected by COVID-19 is the liver and there is an increase of liver enzymes in $15.0 \%$ to $53.0 \%$ of COVID-19 patients [18]. The mechanism of liver injury in COVID-19 patients is multifactorial (Figure 2).

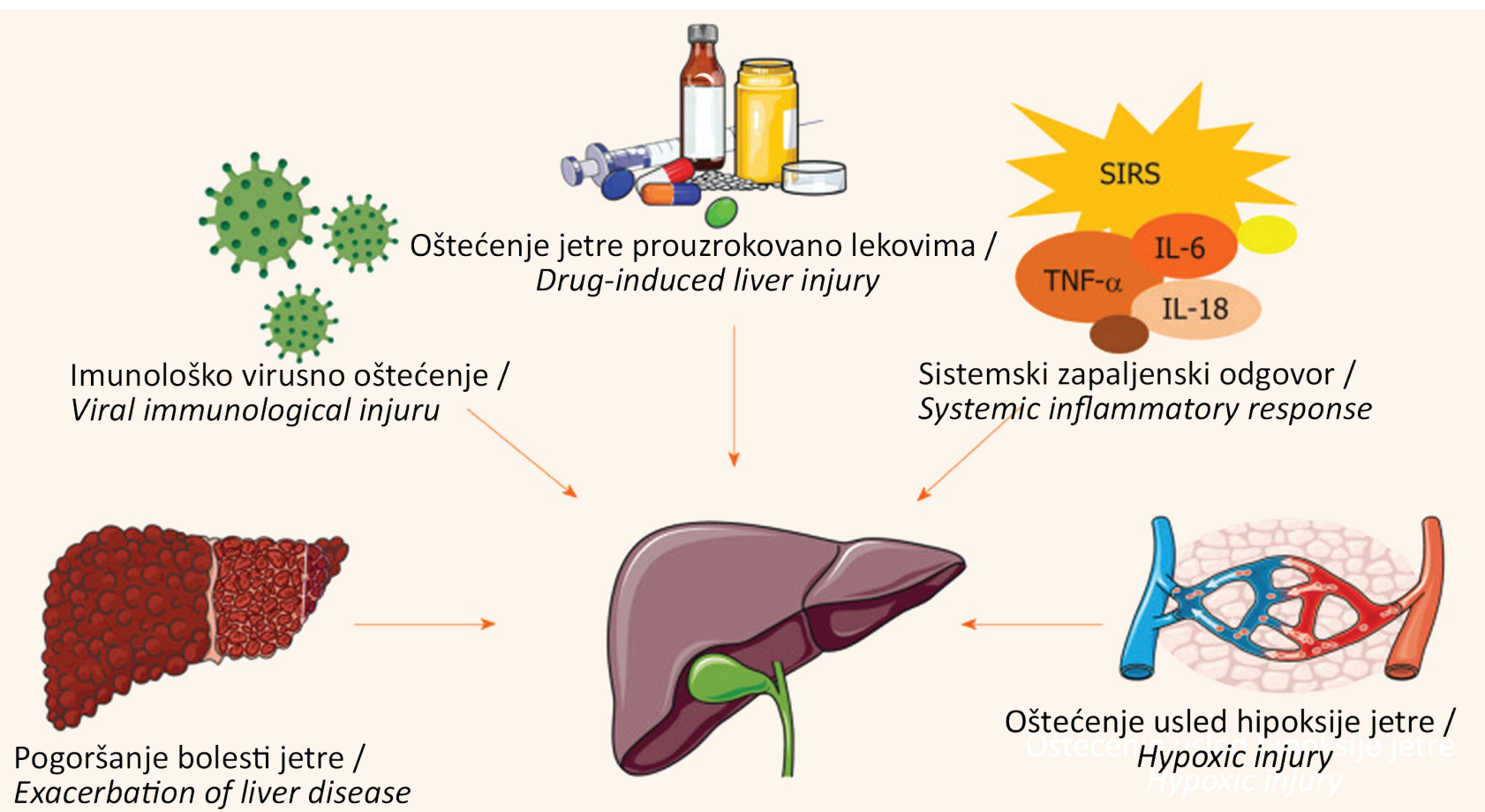

Slika 2. Mehanizmi oštećenja jetre kod KOVID-19 pacijenata.

Preuzeto sa: https://dx.doi.org/10.3748/wjg.v26.332.4753. (Yang RX, Zheng RD, Fan JG. Etiology and management of liver injury in patients with COVID-19. World J Gastroenterol. 2020; 26(32): 4753-4762)
Figure 2. Mechanisms of liver injury in COVID-19 patients

From: https://dx.doi.org/10.3748/wjg.v26.i32.4753. (Yang RX, Zheng RD, Fan JG. Etiology and management of liver injury in patients with COVID-19. World J Gastroenterol. 2020; 26(32): 4753-4762) 


\section{HEPATOLOGIJA}

Drugi organ, nakon pluća, na koji najčešće utiče KOVID-19 infekcija, jeste jetra, a 15,0\% do 53,0\% pacijenata sa KOVID-19 oboljenjem ima povišene vrednosti jetrinih enzima [18]. Više mehanizama dovodi do lezije jetre kod KOVID-19 pacijenata (Slika 2).

Prvi mehanizam, na koji bi se prvo i pomislilo, jeste da sam virus, direktno, inficira jetru i dovodi do pojave lezija [19]. Kako je prethodno navedeno, virus ulazi u ćeliju preko ACE2 receptora, koji je prisutan u većini holangiocita i u manje od 3,0\% hepatocita [7], mada je više pacijenata sa povišenim vrednostima transaminaza [20]. Dakle, može se pretpostaviti da je lezija jetre prouzrokovana infekcijom holangiocita, jer se ACE2 receptori i nalaze u holangiocitima [7], a oni učestvuju u regeneraciji jetre [21].

Postoji još jedna hipoteza, po kojoj SARS-KoV-2 virus ili posrednici zapaljenja, iz creva, putem portne cirkulacije, dospevaju u jetru [22], jer se ACE2 receptori nalaze i u epitelnim ćelijama enterocita u ileumu i debelom crevu $[8,9]$.

Povrh toga, hepatotoksični lekovi, posebno antivirotici i biološka terapija koja blokira interleukin-6 (IL6), ali i antipiretici i antibiotici, imaju direktan uticaj na oštećenje jetre kod ove infekcije [23,24].

Miozitis prouzrokovan KOVID-19 infekcijom se često sreće u kliničkoj praksi, a dobro je poznato da je aspartat aminotransferaza (AST) prisutna $u$ jetrinom $i$ mišićnom tkivu, te i ovim mehanizmom može doći do povišene vrednosti AST-a kod pacijenata obolelih od KOVID-19 infekcije [24].

Osim toga, Kupferove ćelije, odnosno jetrini makrofagi, aktiviraju zapaljenski odgovor pri susretu sa virusom SARS-KoV-2 [22]. Dakle, mogući mehanizam oštećenja jetre u ovoj infekciji može biti sistemsko zapaljenje prouzrokovano citokinskom olujom [23,25].

Poslednje, ali ne i najmanje važno, jeste da je hipoksija, kao rezultat respiratorne insuficijencije, česta pojava u ovoj infekciji, stoga povišene vrednosti transaminaza mogu biti povezane sa ishemijom već hipoksične jetre [26].

Svakako treba voditi računa o KOVID-19 pacijentima koji imaju hronične bolesti jetre, poput ciroze jetre, hepatocelularnog karcinoma, nealkoholne masne bolesti jetre, autoimunog hepatitisa i virusnih hepatitisa, jer takvi pacijenti imaju veći rizik od dekompenzacije i veću stopu mortaliteta [27]. U slučaju hroničnih bolesti jetre, ordinirajući lekar mora odabrati odgovarajuće lekove, koji će sprečiti posledice KOVID-19 infekcije, ali i zaštititi jetrinu funkciju.

\section{Biopsija jetre pacijenata obolelih od KOVID-19} oboljenja

Kako bi se potvrdili ili opovrgli prethodno navedeni mehanizmi oštećenja jetre, neophodne su biopsije jetre sa patohistološkim nalazima pacijenata obolelih
The first mechanism, which comes to mind as the most obvious one, is that the virus itself directly infects the liver and causes the development of lesions [19]. As previously mentioned, the virus enters the cell by latching onto the ACE2 receptor, which is present in most cholangiocytes and in less than $3.0 \%$ of hepatocytes [7], even though there are more patients with increased transaminases [20]. Therefore, it can be assumed that liver lesions may be caused by the infection of cholangiocytes, as ACE2 receptors are, in fact, found in cholangiocytes [7], and they participate in liver regeneration [21].

There is also the hypothesis that SARS-CoV-2 or inflammatory mediators from the intestine can use the portal circulation to invade the liver [22], as ACE2 receptors are also found in epithelial cells of enterocytes in the ileum and colon $[8,9]$.

Moreover, hepatotoxic drugs, especially antivirals and biological therapy targeting interleukin-6 (IL-6), but also antipyretics and antibiotics, have direct impact on liver injury in this infection $[23,24]$.

COVID-19-associated myositis is often seen in clinical practice, and it is known that aspartate aminotransferase (AST) is present in both liver and muscle tissue, so this may be an additional mechanism causing an increased level of AST in COVID-19 patients [24].

Furthermore, Kupffer cells, also known as hepatic macrophages, activate an inflammatory response when they encounter the SARS-CoV-2 virus [22]. Therefore, a possible mechanism of liver injury in this infection can be a systemic inflammation caused by a cytokine storm $[23,25]$.

Last, but not least, hypoxia happens frequently in COVID-19, due to respiratory failure. Consequently, increased transaminase levels may also be connected to ischemia in an already hypoxic liver [26].

Particular attention should, therefore, be given to COVID-19 patients with pre-existing chronic liver diseases such as cirrhosis, hepatocellular carcinoma, nonalcoholic fatty liver disease, autoimmune hepatitis and viral hepatitis, as these patients have a higher risk of decompensation and mortality [27]. In case of pre-existing chronic liver disease, it is up to the attending physician to choose the appropriate medication that can both prevent consequences of the COVID-19 infection and protect liver function.

\section{Liver biopsy in COVID-19 patients}

Pathohistological findings of liver biopsies in COVID-19 patients are necessary in order to verify or disprove the previously described mechanisms of liver injury. Within a previous study, liver biopsy was performed and the pathohistological finding showed apoptotic 
od KOVID-19 infekcije. U sklopu jednog istraživanja, učinjena je biopsija jetre, a patohistološki nalaz ukazao je na apoptozu hepatocita bez prisustva virusa, ali sa lakim do srednje teškim fokalnim lobularnim zapaljenjem [28]. Imunohistohemijom viđena je aktivacija Kupferovih ćelija [28]. Potom su transmisionim elektronskim mikroskopom viđene čestice koronavirusa u citoplazmi hepatocita [28]. Dodatno, mitohondrije tih hepatocita su bile nabrekle, a viđena je i dilatacija endoplazmatičnog retikuluma, kao i oštećena ćelijska membrana, što ukazuje na to da je KOVID-19 oboljenje prouzrokovalo citopatiju [28]. U navedenom istraživanju su bila uključena dva slučaja biopsije jetre iz kojih se može zaključiti da se SARS-KoV-2 virus zaista može proširiti u taj organ, ali nema dokaza o oštećenju jetre prouzrokovanom hepatotoksičnim lekovima, niti o oštećenju usled ishemije i hipoksične jetre [28].

\section{ZAKLJUČAK}

Gastrointestinalne simptome i leziju jetre često srećemo kod pacijenata obolelih od KOVID-19 infekcije, što potvrđuje da je ovo sistemska bolest koja oštećuje više organa. Ono što mora biti istaknuto, kao bitno u kliničkoj praksi, jesu endoskopske procedure, koje treba raditi samo u slučaju akutnog gastrointestinalnog krvarenja, kako bi se smanjio rizik prenošenja infekcije izazvane SARS-KoV-2 virusom. Takođe, u kliničkoj praksi su bitni pacijenti oboleli od IBD oboljenja, a kako oni nisu u grupi pacijenata sa visokim rizikom od oboljevanja od KOVID-19 infekcije, preporuke su da se redovna, hronična terapija treba nastaviti. Poslednje, ali ne i najmanje važno, oštećenje jetre prouzrokovano KOVID-19 infekcijom predstavlja stvaran problem, te je takve pacijente neophodno pomno pratiti, posebno ukoliko već boluju od neke hronične bolesti jetre.

Sukob interesa: Nije prijavljen.

\section{LITERATURA / REFERENCES}

1. Villapol S. Gastrointestinal symptoms associated with COVID-19: impact on the gut microbiome. Transl Res. 2020 Dec;226:57-69. doi: 10.1016/j. trsl.2020.08.004.

2. Lu H, Stratton CW, Tang YW. Outbreak of pneumonia of unknown etiology in Wuhan, China: The mystery and the miracle. J Med Virol. 2020 Apr;92(4):4012. doi: 10.1002/jmv.25678.

3. Lu R, Zhao X, Li J, Niu P, Yang B, Wu H, et al. Genomic characterisation and epidemiology of 2019 novel coronavirus: implications for virus origins and receptor binding. Lancet. 2020 Feb 22;395(10224):565-74. doi: 10.1016/ S0140-6736(20)30251-8.

4. Yeo C, Kaushal S, Yeo D. Enteric involvement of coronaviruses: is faecal-oral transmission of SARS-CoV-2 possible? Lancet Gastroenterol Hepatol. 2020 Apr;5(4):335-7. doi: 10.1016/S2468-1253(20)30048-0. hepatocytes without viral inclusions, but with mild to moderate focal lobular inflammation [28]. Kupffer cell activation was indicated by immunohistochemistry [28]. Furthermore, transmission electron microscope examination revealed coronavirus particles in the cytoplasm of the hepatocytes [28]. In addition, the hepatocytes had swollen mitochondria, a dilatated endoplasmic reticulum and an impaired cell membrane, indicating that COVID-19 had caused cytopathy [28]. From the two liver biopsy cases included in this study, it can be concluded that SARS-CoV-2 can, indeed, disseminate in the liver, but there was no evidence of hypoxic-ischemic liver injury, nor of drug-induced liver injury [28].

\section{CONCLUSION}

Gastrointestinal tract symptoms and liver injury are frequently seen in KOVID-19 patients confirming it to be a systemic disease with multiple organ damage. What needs to be highlighted, as important in clinical practice, is that endoscopic procedures should be done only in case of acute gastrointestinal bleeding, in order to reduce the risk of SARS-CoV-2 transmission. Also, clinically, as IBD patients do not belong to the category of patients who are at increased risk of contracting the COVID-19 infection, the regular therapy for their chronic issues should be continued. Last, but not least, liver injury caused by COVID-19 is a real issue and these patients should be closely monitored, especially if they also have a preexisting chronic liver disease.

\section{Conflict of interest: None declared.}

5. Galanopoulos M, Gkeros F, Doukatas A, Karianakis G, Pontas C, Tsoukalas N, et al. COVID-19 pandemic: Pathophysiology and manifestations from the gastrointestinal tract. World J Gastroenterol. 2020 Aug 21;26(31):4579-88. doi: 10.3748/wjg.v26.i31.4579.

6. Schmulson M, Dávalos MF, Berumen J. Beware: Gastrointestinal symptoms can be a manifestation of COVID-19. Rev Gastroenterol Mex (Engl Ed). 2020 Jul-Sep;85(3):282-7. English, Spanish. doi: 10.1016/j.rgmx.2020.04.001.

7. Chai $X$, Hu L, Zhang $Y$, et al. Specific ACE2 expression in cholangiocytes may cause liver damage after 2019-nCoV infection. bioRxiv. 2020;

8. Zhang H, Kang Z, Gong H, Xu D, Wang J, Li Z, et al. Digestive system is a potential route of COVID-19: an analysis of single- cell coexpression pattern of key proteins in viral entry process. Gut. 2020;69:1010-8. 
9. Xiao F, Tang M, Zheng X, Liu Y, Li X, Shan H. Evidence for Gastrointestinal Infection of SARS-CoV-2. Gastroenterology. 2020 May;158(6):1831-33.e3. doi: 10.1053/j.gastro.2020.02.055.

10. Baj J, Karakuła-Juchnowicz H, Teresiński G, Buszewicz G, Ciesielka M, Sitarz E, et al. COVID-19: Specific and Non-Specific Clinical Manifestations and Symptoms: The Current State of Knowledge. J Clin Med. 2020 Jun 5;9(6):1753. doi: 10.3390/jcm9061753.

11. Hajifathalian K, Mahadev S, Schwartz RE, Shah S, Sampath K, Schnoll-Sussman F, et al. SARS-COV-2 infection (coronavirus disease 2019) for the gastrointestinal consultant. World J Gastroenterol. 2020 Apr 14;26(14):154653. doi: 10.3748/wjg.v26.i14.1546.

12. Wu Y, Guo C, Tang L, Hong Z, Zhou J, Dong X, et al. Prolonged presence of SARS-CoV-2 viral RNA in faecal samples. Lancet Gastroenterol Hepatol. 2020 May;5(5):434-5. doi: 10.1016/S2468-1253(20)30083-2.

13. Neurath MF. COVID-19 and immunomodulation in IBD. Gut. 2020 Jul;69(7):1335-42. doi: 10.1136/gutjnl-2020-321269.

14. Hunt RH, East JE, Lanas A, Malfertheiner P, Satsangi J, Scarpignato C, et al. COVID-19 and Gastrointestinal Disease: Implications for the Gastroenterologist. Dig Dis. 2021;39(2):119-39. doi: 10.1159/000512152.

15. Massironi S, Viganò C, Dioscoridi L, Filippi E, Pagliarulo M, Manfredi G, et al. Endoscopic Findings in Patients Infected With 2019 Novel Coronavirus in Lombardy, Italy. Clin Gastroenterol Hepatol. 2020 Sep;18(10):2375-7. doi: 10.1016/j.cgh.2020.05.045.

16. Popadic V, Klasnja S, Milic N, Rajovic N, Aleksic A, Milenkovic M, et al. Predictors of Mortality in Critically III COVID-19 Patients Demanding High 0xygen Flow: A Thin Line between Inflammation, Cytokine Storm, and Coagulopathy. Oxid Med Cell Longev. 2021 Apr 20;2021:6648199. doi: $10.1155 / 2021 / 6648199$.

17. Monteleone G, Ardizzone S. Are Patients with Inflammatory Bowel Disease at Increased Risk for Covid-19 Infection? J Crohns Colitis. 2020 Sep 16;14(9):1334-6. doi: 10.1093/ecco-jcc/jjaa061.

18. Xu L, Liu J, Lu M, Yang D, Zheng X. Liver injury during highly pathogenic human coronavirus infections. Liver Int. 2020 May;40(5):998-1004. doi: 10.1111/liv.14435.
19. Garrido I, Liberal R, Macedo G. Review article: COVID-19 and liver disease-what we know on 1st May 2020. Aliment Pharmacol Ther. 2020 Jul;52(2):26775. doi: 10.1111/apt.15813.

20. Jothimani D, Venugopal R, Abedin MF, Kaliamoorthy I, Rela M. COVID-19 and the liver.J Hepatol. 2020 Nov;73(5):1231-40. doi: 10.1016/j.jhep.2020.06.006.

21. Banales JM, Huebert RC, Karlsen T, Strazzabosco M, LaRusso NF, Gores GJ. Cholangiocyte pathobiology. Nat Rev Gastroenterol Hepatol. 2019 May;16(5):269-81. doi: 10.1038/s41575-019-0125-y.

22. Bertolini A, van de Peppel IP, Bodewes FAJA, Moshage H, Fantin A, Farinati F, et al. Abnormal Liver Function Tests in Patients With COVID-19: Relevance and Potential Pathogenesis. Hepatology. 2020 Nov;72(5):1864-72. doi: 10.1002/hep.31480.

23. Li J, Fan JG. Characteristics and Mechanism of Liver Injury in 2019 Coronavirus Disease. J Clin Transl Hepatol. 2020 Mar 28;8(1):13-7. doi: 10.14218/ JCTH.2020.00019.

24. Bangash MN, Patel J, Parekh D. COVID-19 and the liver: little cause for concern. Lancet Gastroenterol Hepatol. 2020 Jun;5(6):529-30. doi: 10.1016/ S2468-1253(20)30084-4.

25. Sun J, Aghemo A, Forner A, Valenti L. COVID-19 and liver disease. Liver Int. 2020 Jun;40(6):1278-81. doi: 10.1111/liv.14470.

26. Hajifathalian K, Krisko T, Mehta A, Kumar S, Schwartz R, Fortune B, et al.; WCM-GI research group*. Gastrointestinal and Hepatic Manifestations of 2019 Novel Coronavirus Disease in a Large Cohort of Infected Patients From New York: Clinical Implications. Gastroenterology. 2020 Sep;159(3):1137-40. e2. doi: 10.1053/j.gastro.2020.05.010.

27. Mohammed A, Paranji N, Chen PH, Niu B. COVID-19 in Chronic Liver Disease and Liver Transplantation: A Clinical Review. J Clin Gastroenterol. $2021 \mathrm{Mar}$ 1;55(3):187-94. doi: 10.1097/MCG.0000000000001481.

28. Wang Y, Liu S, Liu H, Li W, Lin F, Jiang L, et al. SARS-CoV-2 infection of the liver directly contributes to hepatic impairment in patients with COVID-19. J Hepatol. 2020;73(4):807-16. 